\title{
Effects of local Polynesian plants and algae on growth and expression of two immune-related genes in orbicular batfish (Platax orbicularis)
}

\author{
Reverter Miriam ${ }^{1}$, Saulnier Denis ${ }^{2}$, David R. ${ }^{2,}{ }^{3}$, Bardon-Albaret Agnes ${ }^{2}$, Belliard Corinne ${ }^{2}$, \\ Bontemps N. ${ }^{1}$, Lecchini D. ${ }^{1}$, Sasal P. ${ }^{1}$
}

${ }^{1}$ CRIOBE, USR3278-CNRS/EPHE/UPVD, Paris Sciences et Lettres (PSL), University of
PerpignanViaDomitia, 52 Avenue Paul Alduy, 66860 Perpignan, France
2 Ifremer, UMR 241 EIO, UPF-ILM-IRD, B.P. 49, 98719 Taravao, Tahiti, French Polynesia
${ }^{3}$ Service de la Pêche BP 20 Papeete, Tahiti 98713, French Polynesia

\begin{abstract}
:
The emerging orbicular batfish (Platax orbicularis) aquaculture is the most important fish aquaculture industry in French Polynesia. However, bacterial infections are causing severe mortality episodes. Therefore, there is an urgent need to find an effective management solution. Besides the supplying difficulty and high costs of veterinary drugs in French Polynesia, batfish aquaculture takes place close to the coral reef, where use of synthetic persistent drugs should be restricted. Medicinal plants and bioactive algae are emerging as a cheaper and more sustainable alternative to chemical drugs. We have studied the effect of local Polynesian plants and the local opportunistic algae Asparagopsis taxiformis on batfish when orally administered. Weight gain and expression of two immune-related genes (lysozyme $\mathrm{g}$ - Lys $\mathrm{G}$ and transforming growth factor beta - TGF- $\beta 1$ ) were studied to analyze immunostimulant activity of plants on $P$. orbicularis. Results showed that several plants increased Lys $G$ and TGF- $\beta 1$ expression on orbicular batfish after 2 and 3 weeks of oral administration. $A$. taxiformis was the plant displaying the most promising results, promoting a weight gain of $24 \%$ after 3 weeks of oral administration and significantly increasing the relative amount of both Lys $G$ and TGF- $\beta 1$ transcripts in kidney and spleen of $P$. orbicularis.
\end{abstract}

\section{Highlights}

- Different plants and algae were orally administered to orbicular batfish. Immune-related gene primers were for the first time identified in Platax orbicularis. Several plants increased the relative expression levels of Lys G and TGF- $\beta 1$ genes. Asparagopsis taxiformis induced a weight gain in $P$. orbicularis fingerlings. A. taxiformis increased immune-related genes expression in $P$. orbicularis. 
Keywords : Orbicular batfish, Asparagopsis taxiformis, Immunostimulant, Lysozyme G, Transforming growth factor, Relative gene expression

\section{Introduction}

World aquaculture production keeps steadily growing, reaching 70.2 million tons of farmed fish in 2013, an increase of $5.6 \%$ from 2012 (FAO, 2014). However, aquaculture growth is often linked to culture intensification, which leads to overcrowding and poor water quality and facilitates the spread of pathogens and disease outbreaks (Bondad-Reantaso et al. 2005). Several drugs, like antibiotic and anthelmintic drugs, 
are commonly used by fish farmers to prevent and treat disease outbreaks (Rico et al. 2013). However, the intensive use of drugs presents numerous disadvantages and can cause 1) accumulation in the muscle of commercialized animals, 2) development of resistance and 3) undesirable effects on the local environment (e.g. Cabello, 2006; Marshall and Levy, 2013). Besides, the rising cost of prescription drugs also limits their application in many developing countries where aquaculture is one of the main supplies of animal protein (Hoareau and DaSilva, 1999). Medicinal plants appear to be a more sustainable and accessible alternative to synthetic drugs, and can at the same time boost fish fitness and immunity and help in pathogen prevention and treatment (Reverter et al. 2014). Medicinal plants have been reported to promote weight gain and enhance immunity in fish and shellfish as well as display antibacterial, antiviral, antifungal and antiparasitic activities against numerous aquaculture pathogens (Reverter et al. 2014). For example, oral administration of garlic powder (Allium sativum) promoted weight, enhanced immunity, showed antibacterial effects against Aeromonas hydrophila and Vibrio harveyi and antiparasitic effects against Neobenedenia sp. in several fish species (Sahu et al. 2007; Talpur and Ikhwanuddin, 2012; Militz et al. 2013). Turmeric (Curcuma longa) and ginger (Zingiber officinalis) also showed immunostimulant, antibacterial, antifungal, antiviral and antiparasitic effects on fish and shellfish (Dügenci et al. 2003; Nya and Austin, 2009; Sahu et al. 2008). Some recent studies are also showing the promising potential of some algae in disease treatment and prevention in aquaculture (Dubber and Harder, 2008). Algae are considered to be a rich source of bioactive molecules and several in vitro studies have showed antibacterial, antiviral, antifungal and antiparasitic activities in different algae extracts (Choudhury et al. 2005; Hutson et al. 2012; Genovese et al. 2013). For example, the red algae Asparagopsis taxiformis displayed antibacterial, antifungal and antiparasitic activities against several fish pathogens and enhanced immune system of Penaeus monodon (Genovese et al. 2012, 2013; Manilal et al. 2013).

Orbicular batfish (Platax orbicularis - Forsskâl, 1775, Ephippidae) live in brackish and marine waters around coral reefs, and is highly appreciated by the Polynesian and Chinese communities for its high quality meat and taste (Gasset and Remoissenet, 2011). P. orbicularis aquaculture is an emerging industry in French Polynesia, but advances in the control of its biological cycle together with the high economic value of this fish species, have contributed in its rapid development, mainly concentrated on Tahiti Island. However, orbicular batfish farming in Tahiti is suffering severe mortality episodes due to bacterial infections caused jointly by $V$. harveyi and Tenacibaculum maritimum shortly after the transfer of hatchery fingerlings to off- 
shore cages (D.Saulnier, pers. commun.). Since batfish aquaculture takes place close to coral reefs, synthetic drug utilization should be restricted and alternative treatments are required.

In the present study, we evaluate the capacity of some common medicinal Polynesian plants (garlic A. sativum, turmeric - C. longa, ginger - Z. marginalis and noni - Morinda taxifolia) and algae (A. taxiformis) to increase expression of immune-related genes (lysozyme $\mathrm{g}$ and transforming growth factor) in orbicular batfish fingerlings when administered orally. Weight gain or loss of treated fish compared to control was also monitored to evaluate the effect of plants on fish appetite. Plants and algae were chosen according to reported bioactivities and local ethnobotanical knowledge (Sahu et al. 2007, 2008; Nayak and Mengi, 2009; Nya and Austin, 2009).

\section{Materials and methods}

\subsection{P. orbicularis fingerlings and sampling}

Healthy fingerlings of $P$. orbicularis were obtained from the Vaia hatchery located in Vairao (Tahiti, French Polynesia). Fish were placed in flow through $200 \mathrm{~L}$ tanks (35 fish per tank) with a water renewal of 100L/h and aeration via an airstone. Temperature, salinity and dissolved oxygen were measured daily and the unfed and fecal materials were removed once a day. Fish were fed 4 times a day with commercial food AL2G (Le Gouessant, Lamballe, France). Administered food quantities were precisely determined according to a feeding ratio based on standard production, which evolves with fish growth (5 to $10 \%$ of biomass depending on fish age, Gasset and Remoissenet, 2011). Experiments were carried out in triplicate tanks (3 tanks per treatment) and fish were sampled ( 3 fish/tank) after two or three weeks of treatment. Fish were weighted and spleen and kidney were collected aseptically and stored in RNA later (Ambion, Austin Texas, USA) at $-80^{\circ} \mathrm{C}$ until RNA extraction (less than 2 months from collection time for most of the samples).

\subsection{Diet}

Fresh plant material (garlic - A. sativum, ginger - Z. officinalis, and turmeric $-C$. longa) was bought from local farmers, whereas noni (M. citrifolia) was collected in the Moorea rainforest (French Polynesia) and the red algae A. taxiformis was collected on the coral reef outer slope in Moorea. Noni and A. taxiformis as well as pealed garlic, ginger and turmeric bulbs were freeze-dried, powdered and stored at $-20^{\circ} \mathrm{C}$ until used. Enriched diets were prepared adding 3\% of sunflower oil, $3 \%$ of cod liver oil and the chosen proportion of 
the plant per $\mathrm{kg}$ of commercial fish food (Table 1). The plant enrichment proportion of $3 \%$ was chosen as a

103

104

105

106

107

108

109

$111 \quad$ 2.3. Immune-related gene expression study

112

113

114 activity in particular.

Table 1.Dietary plant enrichment specifications.

\subsubsection{Primer design}

standard dose to evaluate efficacy differences between plants and then, two doses ( 3 and $1.5 \%)$ were selected for A. taxiformis to evaluate the dose effect on gene expression of immune-related genes. Control diet was also prepared with $3 \%$ of sunflower oil and $3 \%$ of cod liver oil to maintain the lipid content. One experiment without oil enrichment was also performed to study the effect of oil on fish physiology and immunostimulant

\begin{tabular}{ccc}
\hline Plant & $\begin{array}{c}\text { 2 weeks treatment } \\
\text { \% in fish food }(\mathbf{w} / \mathbf{w})\end{array}$ & $\begin{array}{c}\text { 3 weeks treatment } \\
\text { \% in fish food }(\mathbf{w} / \mathbf{w})\end{array}$ \\
\hline Morinda taxifolia & - & 3 \\
Zingiber officinalis & - & 3 \\
Allium sativum & 3 & - \\
Curcuma longa & 3 & - \\
Asparagopsis taxiformis & 3 & $3,1.5$ \\
\hline
\end{tabular}

Since $P$. orbicularis is a non-model fish species, no sequences of immune-related or possible housekeeping genes were available on the GenBank database. Therefore, several primer sets were selected on the basis of a multiple alignment of nucleotide sequences of transforming growth factor (TGF- $\beta 1$ ), lysozyme G (Lys G) and alpha-actin genes ( $\alpha$-actin) from other fish species. Both lysozyme $G$ and transforming growth factor genes were selected due to their key role in fish immune defense, and their potent regulatory activities on other immune molecules such as cytokines and complement (Li et al. 2006; Saurabh and Sahoo, 2008). These primers were designed using conserved regions of each gene and with Primer3 software to allow an optimal annealing temperature of $60^{\circ} \mathrm{C}+/-2^{\circ} \mathrm{C}$. Control or invariant internal genes were necessary for the global normalization of the quantification by real-time PCR (qPCR). The targeted candidate control genes were $\alpha$-actin and elongation factor alpha $(\mathrm{EF} 1 \alpha)$, which were validated in several other fish species (Varsamos et al. 2006; Tang et al. 2007; Mo et al. 2014).

A total of 17 combinations of forward and reverse primers $(4 \mu \mathrm{M})$ for the 4 genes were analyzed by qPCR on dilutions of a reference cDNA sample obtained from a pool of cDNAs from spleen and kidney $P$. orbicularis tissues (see next section below). For each primer combination, seven series of dilutions tested in triplicate 
were used to establish the relationship between threshold cycle $(\mathrm{Ct}) \mathrm{qPCR}$ values and $\log 10$ of the reference cDNA template. Couple of primers yielding both a qPCR efficiency ratio of almost $100 \%$ (restricted to a range between 90 and 110\%), and the higher qPCR sensitivity, as expressed as the lowest cycle threshold $(\mathrm{Ct})$ values for a given dilution, were selected. The specificity of the retained couple of primers was firstly checked by electrophoresis on a $1 \%$ agarose gel of qPCR products, using a DNA fluorescent dye and a DNA molecular weight marker and visualizing a single amplicon of the attempted size. Finally four amplicons of each targeted gene were purified on a QIAEX II gel extraction kit (Qiagen, Courtaboeuf, France), cloned on TOPO® TA cloning ${ }^{\circledR}$ kit (Invitrogen, CergyPontoise, France) and sequenced. For each targeted gene, one single sequence was obtained and deposited in GenBank database (Table 2) after verifying edited sequence by Basic Local Alignment Search Tool (BLAST).

Table 2. Characteristics of the primers used to amplify the different genes.

\begin{tabular}{ccccc}
\hline Gene & Oligonucleotide sequences (5'-3') & $\begin{array}{c}\text { qPCR efficiency } \\
(\mathbf{\%})\end{array}$ & $\begin{array}{c}\text { Amplicon } \\
\text { Length (bp) }\end{array}$ & Accession n \\
\hline EF1 $\alpha$ & $\begin{array}{c}\text { GGCTGGTATCTCCAAGAACG } \\
\text { GTCTCCAGCATGTTGTCTCC }\end{array}$ & 106 & 239 & KU950348 \\
$\alpha$-actin & $\begin{array}{c}\text { GACTACCTCATGAAGATCCTGAC } \\
\text { AGCTTCTCCTTGATGTCACG }\end{array}$ & 102 & 89 & KU976283 \\
Lys G & $\begin{array}{c}\text { GCTCTCATTGCTGCCATCAT } \\
\text { TCAACCTGCATCAGTCCCA }\end{array}$ & 98 & 100 & KU976284 \\
TGF- $\beta 1$ & $\begin{array}{c}\text { TCCCTCTACAACAGCACCAAG } \\
\text { CAGGACCCCATGCAGTAGTT }\end{array}$ & 93 & 758 & KU950349 \\
\hline
\end{tabular}

cDNA synthesis and gene expression analysis.

141 RNA was isolated from $P$. orbicularis spleen and kidney tissues using the kit «SV Total RNA Isolation 142 System» from Promega (Madison, WI, USA). Disruption of the cells was carried out by agitation with metal 143 beads for $15 \mathrm{~min}$ (30 agitations/s) using a bead-beating device. Concentration of the nucleic acids was 144 quantified by measuring the absorbance at $260 \mathrm{~nm}$ using a Thermo Scientific Nanodrop 1000 145 Spectophotometer (Wilmington, Pennsylvania, USA). Purity of the samples was checked by measuring the 146 ratio of OD 260/280 $\mathrm{nm}$ and 230/260 nm, and samples with a ratio lower than 1.8 or higher than 2.1 were 147 purified again by isopropanol and ethanol precipitations. cDNA was generated using the «Transcriptor First 148 Strand - DNA Synthesis kit» from Roche (Roche Applied Science, Penzberg, Germany) and 500 ng of total 149 RNA. Each cDNA sample amplification was performed in duplicate using a Mx3000P thermal cycler 150 (Agilent Technologies, Santa Clara, California, USA). Each reaction contained $12.5 \mu \mathrm{L}$ of Brilliant II SYBR 151 Green qPCR Master Mix (Agilent Tech.), $4 \mu \mathrm{M}$ forward and reverse primer and $10 \mu \mathrm{L}$ of template formerly 
diluted at 1:100 in pure water, in a final reaction volume of $25 \mu 1$. The cycling conditions were $10 \mathrm{~min}$ at $95^{\circ} \mathrm{C}$ to allow the enzyme activation followed by 40 cycles (denaturation $30 \mathrm{~s}$ at $95^{\circ} \mathrm{C}$, annealing 1 min at $60^{\circ} \mathrm{C}$ and $30 \mathrm{~s}$ extension at $72^{\circ} \mathrm{C}$ ) and $1 \mathrm{~min}$ at $95^{\circ} \mathrm{C}$ and finally increasing temperature from $45^{\circ} \mathrm{C}$ to $95^{\circ} \mathrm{C}$ to obtain the melting curves. Threshold Cycle $\left(\mathrm{C}_{\mathrm{t}}\right)$ value corresponded to the PCR cycle number at which an increase in reported fluorescence above the baseline signals was first detected. The threshold was set using an amplification-based algorithm from the Mx3000 software (Agilent Technologies) for the initial plate. For the other plates an inter-plate calibrator was used to set the threshold manually and ensure the repeatability of measures.

160 The relative expression of TGF- $\beta 1$ and Lys $G$ genes were calculated using the comparative $C_{t}$ method also 161 referred to as the $2^{-\Delta \Delta C t}$ method (Livak and Schmittgen, 2001). Briefly, each immune-related gene expression level in fresh plant material condition was normalized with two housekeeping genes ( $\alpha$-actin and EF1 $\alpha$ ) $\left(\Delta \mathrm{Ct}=\mathrm{Ct}_{\text {target gene }}-\mathrm{C}_{\text {mean housekeeping genes }}\right)$ and compared to the control diet condition $\left(\Delta \Delta \mathrm{Ct}=\Delta \mathrm{Ct}_{\text {target gene }}\right.$ $\left.\Delta \mathrm{Ct}_{\text {control }}\right)$ to yield relative immune-related gene expression rate $\left(2^{-\Delta \Delta C t}\right)$.

$\underline{\text { Statistical analysis }}$

All experimental tests were performed by triplicate and mean \pm S.D. was calculated. Gene expression results were displayed using boxplots (package ggplot2 for $\mathrm{R}$ ), where the median and the first and third quartile were represented. Normality of data distribution (Shapiro-Wilk test) and homogeneity of variances (Levene test) were tested and not satisfied, thus non-parametric tests were used. Mann-Whitney U test was used to

171 identify differences among treatments. Significance level was considered at $\mathrm{P}<0.05$.

\section{Results}

\subsection{Growth}

174 None of the enriched diets (plants and algae) displayed a negative effect on fish growth. Only the fish fed 175 with a diet supplemented in A. taxiformis presented a significantly higher growth $(\mathrm{P}<0.05)$ than those fed 176 with the control diet. Fish fed for two weeks on an enriched diet in A. taxiformis (3\%) presented a weight 177 gain of $13.8 \%$, while fish fed for 3 weeks in A. taxiformis (1.5 and 3\%) presented respectively $23.8 \%$ and $14.8 \%$ weight gain (Table 3 ). 
Table 3. Weight results after the different diet treatments of $P$. orbicularis fingerlings.

\begin{tabular}{ccccccc}
\hline Plant & $\begin{array}{c}\text { Concentration } \\
(\boldsymbol{\%})\end{array}$ & $\begin{array}{c}\text { Lenght of } \\
\text { treatment }\end{array}$ & $\begin{array}{c}\text { Control weight } \\
(\text { mean } \pm \text { S.D. })\end{array}$ & $\begin{array}{c}\text { Treatment } \\
(\text { mean } \pm \text { S.D. })\end{array}$ & $\begin{array}{c}\text { Weight gain } \\
(\%)\end{array}$ & $P$-value \\
\hline Oil control & 3 (vegetal) +3 & 2 & $3.43 \pm 0.65$ & $3.64 \pm 0.74$ & 5.78 & $>0.1$ \\
A. sativum & $($ cod) & 2 & $12.25 \pm 1.06$ & $12.68 \pm 1.24$ & 3.39 & $>0.1$ \\
C. longa & 3 & 2 & $12.25 \pm 1.06$ & $12.28 \pm 1.05$ & 0.24 & $>0.1$ \\
A. taxiformis & 3 & 2 & $3.63 \pm 0.73$ & $4.13 \pm 0.57$ & 13.77 & $<0.05$ \\
A. taxiformis & 3 & 3 & $4.95 \pm 0.8$ & $6.13 \pm 1.17$ & 23.84 & $<0.05$ \\
A. taxiformis & 1.5 & 3 & $4.95 \pm 0.8$ & $5.68 \pm 1.1$ & 14.75 & 0.1 \\
M. taxifolia & 3 & 3 & $12.45 \pm 1.98$ & $12.94 \pm 2.76$ & 3.78 & $>0.1$ \\
Z. officinale & 3 & 3 & $9.70 \pm 1.22$ & $9.64 \pm 0.95$ & -0.62 & $>0.1$ \\
\hline
\end{tabular}

\subsection{Immunomodulatory effect}

183 Two immune-related genes were identified for the first time in P. orbicularis. The relative expression of genes encoding lysozyme g (Lys G) and transforming growth factor (TGF- $\beta 1$ ) were measured in spleen and kidney of $P$. orbicularis.

Since we used a control diet enriched in oil to maintain the same lipid content as our treatment diets, a first assay to test the oil effect on the expression of the studied immune-related genes was performed. Oil did not increase expression level of neither Lys G nor TGF- $\beta 1$ in P. orbicularis fingerlings. Fish fed with an enriched diet in turmeric had significant higher expression of Lys $\mathrm{G}$ in kidney $(\mathrm{P}<0.05$, Figure 1), while fish fed with garlic presented significant higher expression of Lys $\mathrm{G}$ in spleen $(\mathrm{P}<0.05$, Figure 1$)$. Fish fed during 3 weeks with an enriched diet in A. taxiformis (3\%) presented significant higher expression of Lys G in both spleen and kidney and significant higher expression of TGF- $\beta 1$ in kidney $(\mathrm{P}<0.05$, Figure 1 and 2$)$. Fish fed during 3 weeks with an enriched diet in A. taxiformis (1.5\%) presented significant higher expression levels of Lys g and TGF- $\beta 1$ in kidney ( $\mathrm{P}<0.05$, Figure 1 and 2). However, fish fed with A. taxiformis for 2 weeks did not display an increased expression level of Lys G or TGF- $\beta 1$ in any of the organs. Ginger treated fish displayed a moderately but significant higher expression level of TGF- $\beta 1$ gene in spleen. No immunostimulatory effect was observed with the noni-enriched diet. No immunosuppression effects were observed in any of the treated fish in our experiments.

Figure 1. Lys G relative gene expression on kidney and spleen of $P$. orbicularis following 2 week treatment (a) and 3 week treatment (b) with diets enriched in several plants or algae. Oil enrichment control test is 

first and third quartile, while upper whisker and lower whisker represent maximum and minimum values excluding the outliers (represented as black dots). * indicate $P$-value $<0.05$ (Mann-Whitney U tests).

a) 2 week treatments
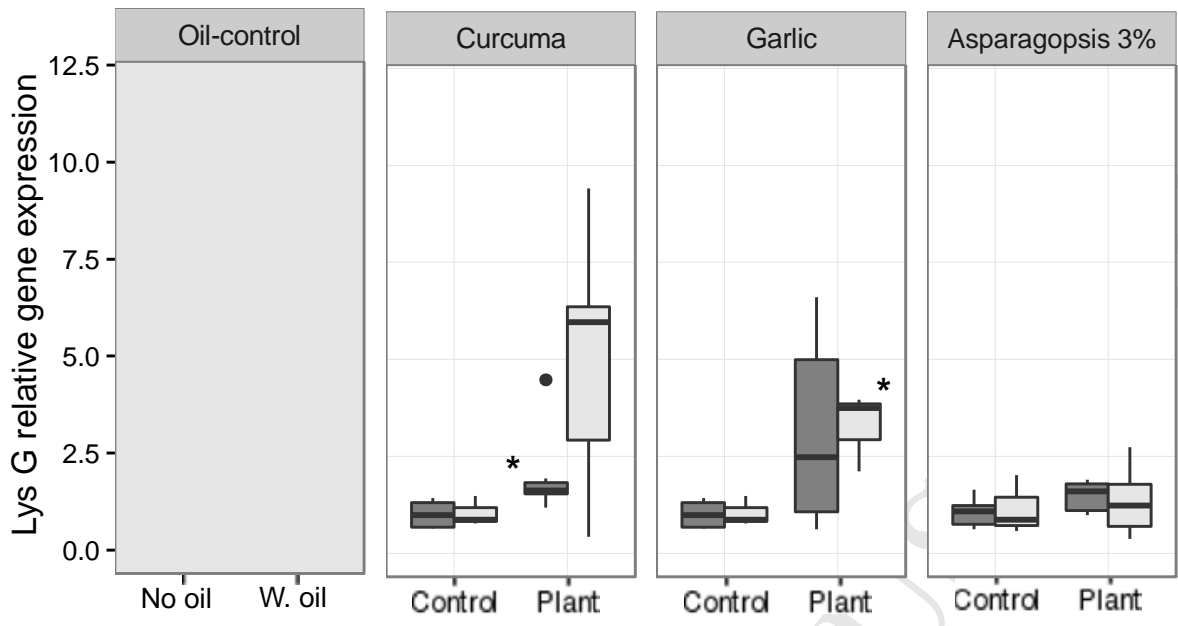

b) $\mathbf{3}$ week treatments
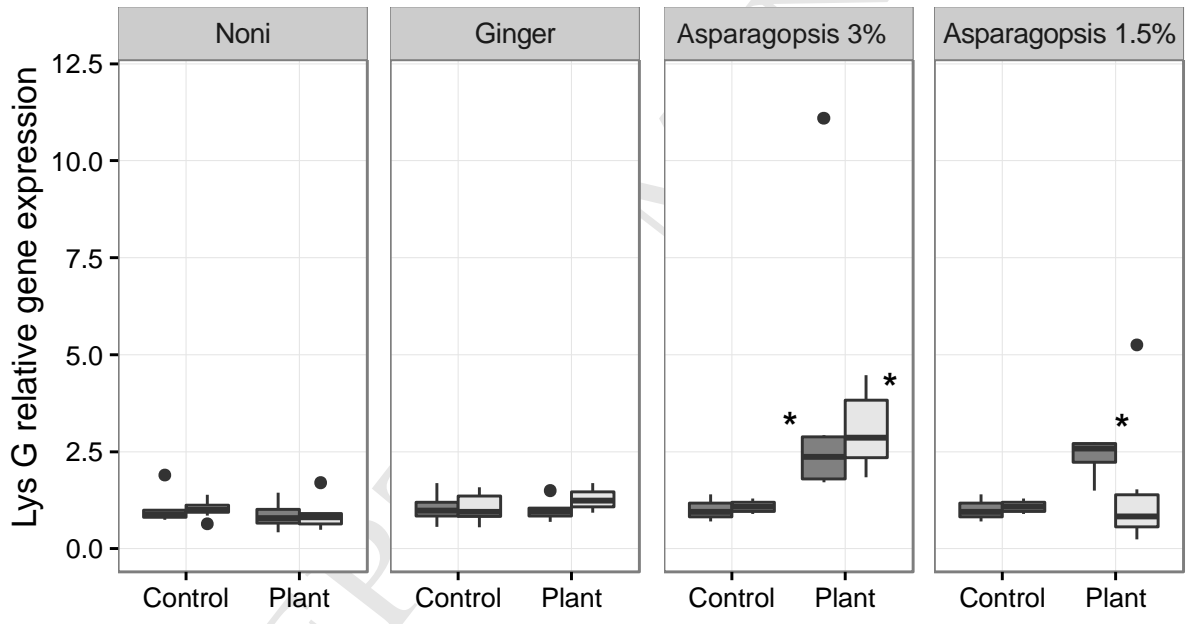

Figure 2. TGF- $\beta 1$ relative gene expression on kidney and spleen of $P$. orbicularis following 2 week treatment (a) and 3 week treatment (b) with diets enriched in several plants or. No-oil stands for commercial food alone, and W. oil represents commercial food enriched in oil (control used in the rest of the experiments). Upper hinge and lower hinge represent the first and third quartile, while upper whisker and lower whisker represent maximum and minimum values excluding the outliers (represented as black dots). * 
a) 2 week treatments
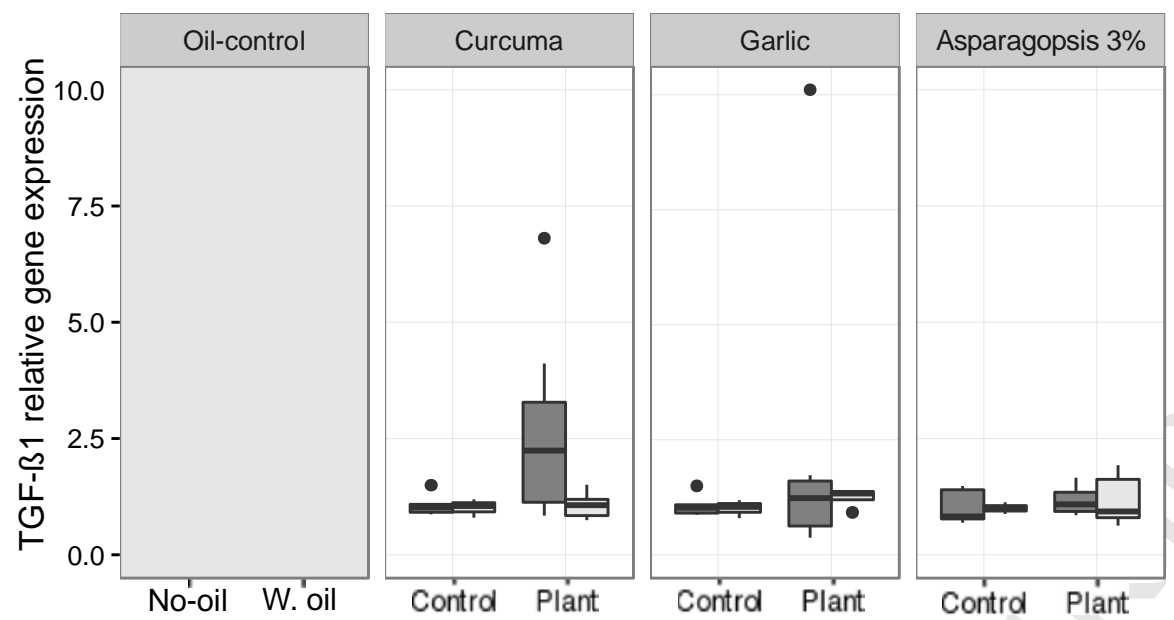

\section{b) 3 week treatment}
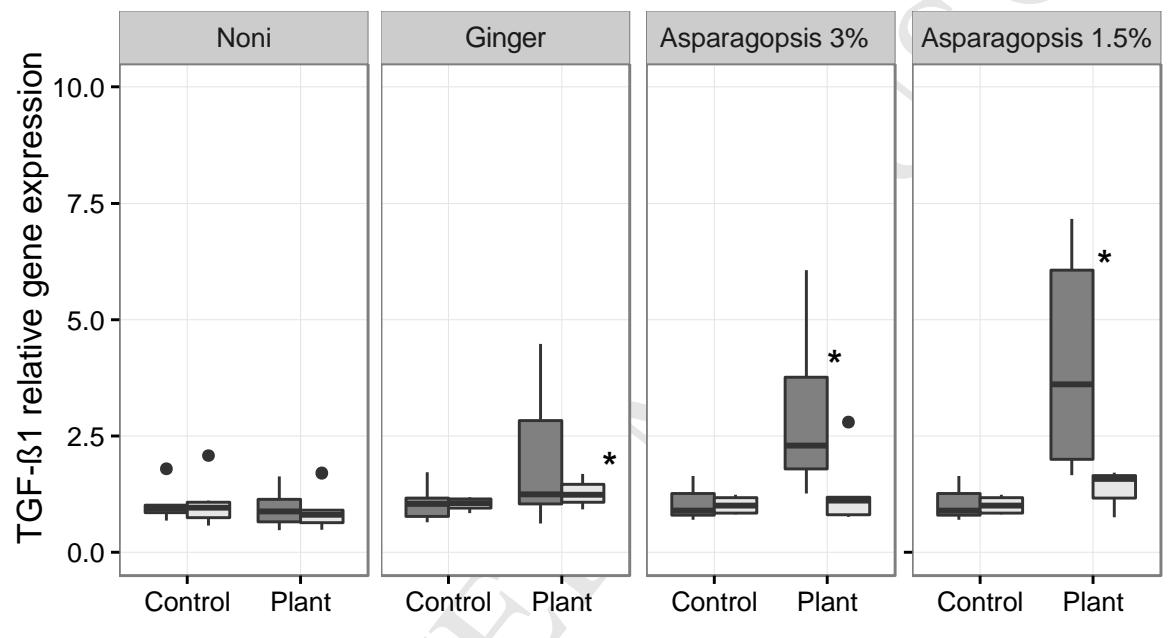

4. Discussion

An increasing number of studies report medicinal plant bioactivities in fish and against fish pathogens, making bioactive plants and algae a new alternative to prevent and treat disease outbreaks in aquaculture (Reverter et al. 2014). Our study has revealed the potential of several local Polynesian plants and algae to enhance the expression of two immune-related genes (Lys G and TGF- $\beta 1$ ) in orbicular batfish after 2 and/or 3 weeks of oral administration.

Lysozyme is a bacteriolytic enzyme that acts disrupting mucopolysaccharides in the bacterial cell walls, causing bacteria death (Chipman and Sharon, 1969). Lysozyme can also trigger other immune responses such as the complement system and phagocytic cells (Magnadottir, 2006). Therefore, lysozymes play an important role in the defense of fish and an increased level of lysozyme observed after dietary administration of garlic, turmeric and A. taxiformis, might improve fish performance against pathogenic infections. For 
example, Park and Choi (2012) showed that Nile tilapia (Oreochromis niloticus) fed with diets containing mistletoe (Viscum album coloratum) displayed increased levels of lysozyme and when challenged with the bacteria Aeromonas hydrophila, survivability of treated fish increased by $42 \%$. Several studies have shown an increase of lysozyme and immunostimulant activity in other fish species after ginger, garlic and turmeric dietary administration (Sahu et al. 2008; Nya and Austin, 2009; Talpur and Ikhwanuddin, 2012). We did not observe an increased expression of lysozyme $\mathrm{G}$ after 3 weeks of ginger enriched diet administration. Plant chemodiversity varies between individuals of the same species depending on plant ontogeny, environmental and genetic factors (Moore et al. 2014). Variability in secondary metabolites and biological activities have been reported in ginger species, therefore we could think that the absence of immunostimulatory activity of ginger on $P$. orbicularis fingerlings could be related to the specific ginger chemotype used in this experiment (Homunth, 2008; Ghasemzadeh et al. 2016). However, we can not exclude that maybe ginger dose used (3 $\%)$ or treatment length (3 weeks) could also not be the optimal to observe ginger immunostimulant effect on lysozyme g gene.

Transforming growth factor $\beta$ is an immune regulator cytokine involved in wound repair processes, proinflammatory reactions and haematopoiesis (McCartney-Francis and Wahl, 1994; Lawrence, 1996). Atiba et al. (2011) showed that higher levels of TGF- $\beta 1$ due to Aloe vera administration accelerated wound healing in rats. Other studies have shown that some immunostimulants and probiotics can increase levels of TGF- $\beta 1$ expression in fish (Panigrahi et al. 2007; Awad et al. 2011). In our study, TGF- $\beta 1$ expression increased significantly in the kidney of fish fed with an enriched diet in A. taxiformis for three weeks, and a moderate significant increase was also observed in the spleen of ginger treated fish.

Length of treatment and dose are also important parameters when assessing plant effects on fish physiology, since inappropriate doses can either be not effective or display toxic effects on fish (Kavitha et al. 2012; Militz et al. 2013). In our study, length played a notable effect on the immunostimulant activity of $A$. taxiformis in orbicular batfish, and a week-longer treatment caused a significant higher expression of two immune-related genes. However, we did not observe very different responses between diets with two $A$. taxiformis doses (1.5 and 3\%).

The widely distributed and rapidly spreading red algae A. taxiformis, is known to produce a high diversity of halogenated metabolites with multiple bioactivities (McConnell and Fenical, 1977; Greff et al. 2014, Dijoux et al. 2014; Andreakis et al. 2016). Some chemical ecology studies have shown that Asparagopsis 
brominated metabolites are involved in the control of epiphytic bacterial communities and quorum sensing inhibition activities from $\mathrm{MeOH}$ extracts of A. taxiformis have been found (Paul et al. 2006a; Jha et al. 2013). Paul et al. (2006b) showed that halogenated natural products from the sister species Asparagopsis armata deterred herbivorous feeding. In aquaculture, several studies have shown antibacterial, antifungal and antiparasitic properties of A. taxiformis extracts against fish pathogens (Hutson et al. 2012; Genovese et al. 2012, 2013). However, an in vivo study showed high toxicity of A. taxiformis aqueous extract in barramundi

(Lates calcarifer) (Mata et al. 2013).

This is the first in vivo study to show that A. taxiformis increased growth and expression level of immunerelated genes in fish, when administered orally. In this study we fed $P$. orbicularis fingerlings during 2 and 3 weeks with a diet enriched in A. taxiformis and fish did not show any sign of deterrence due to the bioactive metabolites from the algae but rather an increased appetite and weight gain. Although we did not find any

others to A. taxiformis metabolites, or it is rather the exposure or administration procedure which affects fish susceptibility to the algae. Finally, since A. taxiformis proliferation is increasing in tropical areas like French Polynesia, its commercial use as fish food complement would not involve the introduction of exogenous molecules in the environment (and facility of culturing the algae) (Mantelatto et al. 2013).

\section{Conclusions}

311 This study showed the potential of some plants like garlic, turmeric and A. taxiformis to be integrated in fish diets to increase expression of immune-related genes. This is the first study, where A. taxiformis was orally

313 adminisitered to fish, and results show its capacity to induce weight gain and increase level of two immune314 related genes in the new cultured fish species $P$. orbicularis. Fish fed with garlic, turmeric and A. taxiformis 315 increased the level of Lys $\mathrm{G}$ in the spleen and/or kidney of $P$. orbicularis fingerlings. Fish fed with and enriched diet in A. taxiformis for 3 weeks also increased the level of TGF- $\beta 1$ and promoted weight gain in $P$. orbicularis fingerlings. These data provide interesting information on the effect of A. taxiformis on orbicular batfish immunity, and it shows the promising potential of this algae to be used as a fish complement to promote weight gain and enhance immunity, without the introduction of exogenous molecules into the 
environment. Further studies involving in vivo challenges with pathogens in fish fed with enriched diets in $A$. taxiformis will be needed in order to assess A. taxiformis true potential to prevent or treat diseases outbreaks in aquaculture.

Acknowledgements

Authors would like to thank M.A. Lafille and A. Teissier for their help with the P. orbicularis transfers. This work was supported by the Ministry of Overseas France (MOM Conv. HC 217-13), the National Center for

Scientific Research (CNRS), the Direction of Marine and Mining Ressources (DRMM) and the Polynesian Aquaculture Cooperative. This research is part of an EPHE PhD thesis supported by a Labex "Corail" doctoral grant accorded to M. Reverter.

Bibliography

Andreakis, N., Costello, P., Zanolla, M., Saunders, G.W., Mata, L., 2016. Endemic or introduced? Phylogeography of Asparagopsis (Florideophyceae) in Australia reveals multiple introductions and a new mitochondrial lineage. Journal of Phycology, doi:10.1111/jpy.12373

Atiba, A., Nishimura, M., Kakinuma, S., Hiraoka, T., Goryo, M., Shimada, Y., Ueno, H., Uzuka, Y., 2011. Aloe vera oral administration accelerates acute radiation-delayed wound healing by stimulating transforming growth factor- $\beta$ and fibroblast growth factor production. The American Journal of Surgery 201, 809-818. doi:10.1016/j.amjsurg.2010.06.017

Awad, E., Mitchell, W.J., Austin, B., 2011. Effect of dietary supplements on cytokine gene expression in rainbow trout, Oncorhynchus mykiss (Walbaum). Journal of Fish Diseases 34, 629-634. doi:10.1111/j.1365-2761.2011.01271.x

Bondad-Reantaso, M.G., Subasinghe, R.P., Arthur, J.R., Ogawa, K., Chinabut, S., Adlard, R., Tan, Z., Shariff, M., 2005. Disease and health management in Asian aquaculture. Veterinary Parasitology, From Science to Solutions Plenary Lectures Presented at the 20th Conference of the World Association for the Advancement of Veterinary Parasitology 20th Conference of the World Association for the Advancement of Veterinary Parasitology 132, 249-272. doi:10.1016/j.vetpar.2005.07.005 
Cabello, F.C., 2006. Heavy use of prophylactic antibiotics in aquaculture: a growing problem for human and animal health and for the environment. Environmental Microbiology 8, 1137-1144. doi:10.1111/j.1462-2920.2006.01054.x

Chipman, D.M., Sharon, N., 1969. Mechanism of lysozyme action. Science 165, 454-465.

Choudhury, S., Sree, A., Mukherjee, S.C., Pattnaik, P., Bapuji, M., 2005. In vitro antibacterial activity of extracts of selected marine algae and mangroves against fish pathogens. Asian Fisheries Science 18, $285-294$.

Dijoux, L., Viard, F., Payri, C., 2014. The More We Search, the More We Find: Discovery of a New Lineage and a New Species Complex in the Genus Asparagopsis. PLoS One 9. doi:10.1371/journal.pone.0103826.

Dubber, D., Harder, T. 2008. Extracts of Ceramium rubrum, Mastocarpus stellatus and Laminaria digitata inhibit growth of marine and fish pathogenic bacteria at ecologically realistic concentrations. Aquaculture 274, 196-200. doi: 10.1016/j.aquaculture.2007.11.029.

Dügenci, S.K., Arda, N., Candan, A., 2003. Some medicinal plants as immunostimulant for fish. Journal of Ethnopharmacology 88, 99-106. doi: 10.1016/S0378-8741(03)00182-X.

Food and Agriculture Organization of the United Nations, Fisheries and Aquaculture Department, 2014.The state of world fisheries and aquaculture 2014. Food and Agriculture Organization of the United Nations; Eurospan distributor, Rome; London.

Gasset, É., Remoissenet, G., 2011. Le paraha peue (Platax orbicularis), biologie, pêche, aquaculture et marché. Editions Quae, 63p.

Genovese, G., Faggio, C., Gugliandolo, C., Torre, A., Spanò, A., Morabito, M., Maugeri, T.L., 2012. In vitro evaluation of antibacterial activity of Asparagopsis taxiformis from the Straits of Messina against pathogens relevant in aquaculture. Marine Environmental Research 73, 1-6. doi:10.1016/j.marenvres.2011.10.002

Genovese, G., Leitner, S., Minicante, S.A., Lass-Flörl, C., 2013. The Mediterranean red alga Asparagopsis taxiformis has antifungal activity against Aspergillus species. Mycoses 56, 516-519. doi:10.1111/myc. 12065

Ghasemzadeh, A., Jaafar, H.Z.E., Ashkani, S., Rahmat, A., Juraimi, A.J., Puteh, A. Mohamed, M.T.M., 2016. Variation in secondary metabolite production as well as antioxidant and antibacterial activities 
of Zingiber zerumbet (L.) at different stages of growth. BMC Complement Altern. Med. $16: 104$. doi: 10.1186/s12906-016-1072-6

Greff, S., Zubia, M., Genta-Jouve, G., Massi, L., Perez, T., Thomas, O.P., 2014. Mahorones, highly brominated cyclopentenones from the red alga Asparagopsis taxiformis. Journal of Natural Products

Lawrence, D.A., 1996. Transforming growth factor-beta: a general review. European Cytokine Network 7 , $363-374$.

Li, M.O., Wan, Y.Y., Sanjabi, S., Robertson, A.K., Flavell, R.A., 2006. Transforming growth factor-beta regulation of immune responses. Ann. Rev. Immunol. 24, 99 - 146.

Livak, K.J., and Schmittgen, T. D., 2001. Analysis of relative gene expression data using real-time quantitative PCR and the 2(-Delta Delta C(T)) Method. Methods 25, 402-408.

Magnadóttir, B., 2006. Innate immunity of fish (overview). Fish \& Shellfish Immunology, Reviews in Fish Immunology 20, 137-151. doi:10.1016/j.fsi.2004.09.006

Manilal, A., Selvin, J., Sugathan, S., 2013. Immuno-Modulatory Efficacy of Indian Red Algae, Asparagopsis taxiformis, in Penaeus monodon. Journal of Applied Aquaculture 25, 81-93. doi:10.1080/10454438.2013.76351. 
Mantelatto, M.C., Fleury, B.G., Menegola, C., Creed, J.C., 2013. Cost-benefit of different methods for monitoring invasive corals on tropical rocky reefs in the southwest Atlantic. Journal of Experimental Marine Biology and Ecology 449, 129-134. doi:10.1016/j.jembe.2013.09.009

Marshall, B.M., Levy, S.B., 2013. Food animals and antimicrobials: Impacts on human health. Clinical Microbiology Reviews, 24, 718-733. doi: 10.1128/CMR.00002-11

Mata, L., Wright, E., Owens, L., Paul, N., de Nys, R., 2013. Water-soluble natural products from seaweed have limited potential in controlling bacterial pathogens in fish aquaculture. J. Appl. Phycol. 25, 1963-1973.

McCartney-Francis, N.L., Wahl, S.M., 1994. Transforming growth factor beta: a matter of life and death. Journal of Leukocytes Biology 55, 401-409.

McConnell, O., Fenical, W., 1977. Halogen chemistry of the red alga Asparagopsis. Phytochemistry 16, 367-374. doi:10.1016/0031-9422(77)80067-8

Militz, T.A., Southgate, P.C., Carton, A.G., Hutson, K.S., 2013. Dietary supplementation of garlic (Allium sativum) to prevent monogenean infection in aquaculture. Aquaculture 408-409, 95-99. doi:10.1016/j.aquaculture.2013.05.027

Mo, F., Zhao, J., Liu, N., Cao, L.-H., Jiang, S.-X., 2014. Validation of reference genes for RT-qPCR analysis of CYP4T expression in crucian carp. Genetics and Molecular Biology 37, 500-507.

Moore, B.D., Andrew, R.L., Külheim, C., Foley, W.J., 2014. Explaining intraspecific diversity in plant secondary metabolites in an ecological context. New Phytol. 201, 733-750.

Nayak, S., Mengi, S., 2009. Immunostimulant activity of the extracts and bioactivities of the fruits of Morinda taxifolia. Pharmaceutical Biology 47, 248 - 254. doi :10.1080/13880200802435697.

Nya, E.J., Austin, B., 2009. Use of dietary ginger, Zingiber officinale Roscoe, as an immunostimulant to control Aeromonas hydrophila infections in rainbow trout, Oncorhynchus mykiss (Walbaum). Journal of Fish Diseases 32, 971-977. doi:10.1111/j.1365-2761.2009.01101.x

Panigrahi, A., Kiron, V., Satoh, S., Hirono, I., Kobayashi, T., Sugita, H., Puangkaew, J., Aoki, T., 2007. Immune modulation and expression of cytokine genes in rainbow trout Oncorhynchus mykiss upon probiotic feeding. Developmental \& Comparative Immunology 31, 372-382. doi:10.1016/j.dci.2006.07.004 
Park, K.-H., Choi, S.-H., 2012. The effect of mistletoe, Viscum album coloratum, extract on innate immune response of Nile tilapia (Oreochromis niloticus). Fish \& Shellfish Immunology 32, 1016-1021. doi:10.1016/j.fsi.2012.02.023

Paul, N.A., Nys, R. de, Steinberg, P.D., 2006a. Chemical defence against bacteria in the red alga Asparagopsis armata: linking structure with function. Marine Ecology Progress Series 306, 87-101. doi:10.3354/meps306087

Paul, N.A., Nys, R. de, Steinberg, P.D., 2006b. Seaweed-hervibore interactions at a small scale: direct tests of feeding deterrence by filamentous algae. Marine Ecology Progress Series 323, 1-9. doi:10.3354/meps323001

Reverter, M., Bontemps, N., Lecchini, D., Banaigs, B., Sasal, P., 2014. Use of plant extracts in fish aquaculture as an alternative to chemotherapy: Current status and future perspectives. Aquaculture 433, 50-61. doi:10.1016/j.aquaculture.2014.05.048

Rico, A., Phu, T.M., Satapornvanit, K., Min, J., Shahabuddin, A.M., Henriksson, P.J.G., Murray, F.J., Little, D.C., Dalsgaard, A., Van den Brink, P.J., 2013. Use of veterinary medicines, feed additives and probiotics in four major internationally traded aquaculture species farmed in Asia. Aquaculture 412413, 231-243. doi:10.1016/j.aquaculture.2013.07.028

Sahu, B.K.D., Das, B.K., Mishra, B.K., Pradhan, J., Sarangi, N., 2007. Effect of Allium sativumon the immunity and survival of Labeorohita infected with Aeromonas hydrophila. Journal of Applied Ichthyology 23, 80-86.

Sahu, S., Das, B.K., Mishra, B.K., Pradhan, J., Samal, S.K., Sarangi, N., 2008. Effect of dietary Curcuma longa on enzymatic and immunological profiles of rohu, Labeorohita (Ham.), infected with Aeromonas hydrophila. Aquaculture Research 39, 1720-1730. doi:10.1111/j. $1365-$ 2109.2008.02048.x

Saurabh, S., Sahoo, P.K., 2008. Lysozyme: an important defence molecule of fish innate immune system. Aquaculture Res. 39, 223-239.

Talpur, A.D., Ikhwanuddin, M., 2012. Dietary effects of garlic (Allium sativum) on haemato-immunological parameters, survival, growth, and disease resistance against Vibrio harveyi infection in Asian sea bass, Lates calcarifer (Bloch). Aquaculture 364-365, 6-12. doi:10.1016/j.aquaculture.2012.07.035 
Tang, R., Dodd, A., Lai, D., MeNabb, W.C., Love, D.R., 2007. Validation of zebrafish (Danio rerio) reference genes for quantitative real-time RT-PCR normalization. Acta Biochimica et Biophysica Sinica (Shanghai) 39, 384-390. doi: 10.1111/j.1745-7270.2007.00283.x

463 Varsamos, S., Xuereb, B., Commes, T., Flik, G., Spanings-Pierrot, C., 2006. Pituitary hormone mRNA 464 expression in European seabass Dicentrarchus labrax in seawater and following acclimation to fresh 466 water. Journal of Endocrinology 191, 473-480. doi:10.1677/joe.1.06847.

466 Wolmuth, H., 2008. Phytochemistry and pharmacology of plants from the ginger family, Zingiberaceae. PhD thesis, Southern Cross University, Lismore, NSW. 